\title{
Hubungan Status Gizi dan Aktivitas Fisik dengan Kejadian Hipertensi Remaja
}

\author{
Romadhiyana Kisno Saputri $^{1 *}$, Akhmad Al-Bari ${ }^{1}$, Ria Indah Kusuma Pitaloka ${ }^{1}$ \\ ${ }^{1}$ Program Studi Farmasi Universitas Nahdlatul Ulama Sunan Giri \\ email*: romadhiyana.ks@unugiri.ac.id
}

\begin{abstract}
Adolescence is peak height velocity that affect changes in body composition, rapid growth on weight, bone mass, pysical activity and nutritional status. Overweight and lack of physical activity are risk factors of hyertension in adolescents. Overweight adolescents have a 4,85 times risk of developig hypertension compared to adolescents with normal nutritional status. Lack of physical activity has 7,86 times the risk of developing hypertension than adolescents with active physical activity. Hypertension in adolescents increase risk of morbidity and mortality in adults.

This study aim to determine the correlation between nutritional status and physical activity with hypertension in adolescents. A quantitative research with cross sectional design was developed. Respondents in this study were 75 college students. Data analysis using Spearman's Correlation test.

Proportion of obesity and overweight was 20\%. Physical activity of the respondents belongs to light category. The incidence of hypertension I 14,67\% and hypertension II 2,67\%. Results shows that there was correlation between nutritional status and physical activity with hypertension in adolescents.
\end{abstract}

Keywords : nutritional status, physical activity, hypertension, adolescents

Submitted : 2020-12-15 Accepted : 2021-06-29 Published : 2021-11-08 


\section{PENDAHULUAN}

Masa remaja merupakan puncak pertumbuhan yang akan mempengaruhi perubahan komposisi tubuh, pertumbuhan yang pesat pada berat badan dan masa tulang, dan aktivitas fisik, sehingga mempengaruhi kebutuhan gizi pada remaja akhir (Irdiana and Nindya, 2017). Gizi pada remaja merupakan suatu hal yang harus diperhatikan, banyak dampak yang akan dialami oleh remaja ketika mengalami malnutrisi. Banyak dampak yang akan dialami oleh remaja ketika mengalami malnutrisi, seperti pada remaja yang mengalami gizi lebih atau gemuk akan berisiko terjadinya penyakit degeneratif semakin tinggi (Syahfitri, 2017)

Status gizi lebih pada remaja adalah masalah gizi yang baru dan berkembang di Indonesia dalam beberapa dekade terakhir. Berdasarkan data RISKESDAS 2018, di Indonesia remaja gemuk berusia 16-18 tahun meningkat 2,2\% dibandingkan tahun 2013. Di Jawa Timur, remaja usia 16-18 tahun $11,3 \%$. Penelitian yang dilakukan oleh Setiawati $d k k$, (2019) menunjukkan status gizi gemuk sebesar 14,3\% maupun obesitas sebesar $6,8 \%$. Status gizi lebih menjadi masalah yang serius bagi remaja dan tidak dapat dipandang sebelah mata karena status gizi lebih yang terjadi pada saat remaja 30\% akan berlanjut hingga dewasa (Simbolon, Tafrieani and Dahrizal,
2018).

Aktivitas fisik merupakan perilaku positif sebagai pengontrol keseimbangan energi, setiap gerakan tubuh yang menyebabkan peningkatan pengeluaran atau pembakaran tenaga. Aktivitas fisik yang ringan pada masa remaja akan cenderung kurang aktif pada masa berikutnya (Praditasari dan Sumarmi, 2018). Beberapa penelitian menunjukkan bahwa aktivitas fisik ringan lebih banyak ditemukan pada remaja obesitas dibandingkan dengan remaja non-obesitas (Irdianty, et all 2016). Sebanyak 57,3\% remaja melakukan aktivitas fisik dalam kategori aktivitas fisik ringan. Aktivitas fisik yang ringan menyebabkan keluaran energi menjadi rendah sehingga terjadi ketidakseimbangan antara masukan energi yang lebih banyak dibandingkan dengan energi yang keluar. Hal ini meningkatkan risiko status gizi lebih dan juga penyakit degeneratif seperti hipertensi.

Status gizi lebih dan kurangnya aktifitas fisik merupakan faktor risiko hipertensi pada remaja. Remaja dengan status gizi lebih memiliki risiko 4,85 kali untuk mengalami hipertensi dibandingkan dengan remaja yang memiliki status gizi normal (Shaumi dan Achmad, 2019). Aktivitas fisik tidak aktif merupakan faktor risiko kejadian hipertensi yaitu 7,86 kali berisiko hipertensi dari pada remaja dengan aktivitas fisik aktif 
(Kurnianingtyas dkk; 2017). Hipertensi dapat muncul sejak remaja dan prevalensinya meningkat beberapa tahun terakhir (Shaumi and Achmad, 2019). Pada penelitian yang dilakukan oleh Abaa, dkk, (2017) terdapat 8,3\% persen responden mengalami prehipertensi dan berdasarkan Indeks Massa Tubuh (IMT) memiliki berat badan lebih dan obesitas. Penelitian lain fmenunjukkan sampel dengan IMT berat badan lebih yang mengalami pre-hipertensi 15,8\%, dan hipertensi 5,3\% sedangkan sampel dengan IMT obesitas yang mengalami pre-hipertensi $50 \%$ dan hipertensi 7,7\%. Banyaknya lemak dalam tubuh menyebabkan pembuluh darah menyempit sehingga dapat meningkatkan tekanan darah (Suryawan, 2019). Perkembangan hipertensi dipengaruhi oleh banyak faktor, salah satunya aktifitas fisik. Akfititas fisik berpengaruh terhadap kejadian hipertensi pada pekerja berumur $\geq$ 15 tahun (Hardati dan Ahmad, 2017). Jika berat badan seseorang bertambah, maka volume darah akan bertambah pula, sehingga beban jantung untuk memompa darah juga bertambah. Kurangnya aktivitas fisik meningkatkan resiko menderita hipertensi (Karim, et al, 2018).

Penyakit hipertensi merupakan the silent disease atau penyakit yang tidak diketahui sebab banyak orang yang tidak mengetahui bahwa dirinya terkena hipertensi sebelum memeriksakan tekanan darahnya. Beberapa penelitian menunjukkan bahwa hipertensi dapat muncul sejak remaja dan prevalensinya mengalami peningkatan selama beberapa dekade terakhir, Joint National Comitte (JNC) VII 2013 didapatkan prevalensi nasional sebesar 5,3 persen (laki-laki 6,0\% dan perempuan 4,7\%). Hipertensi yang tidak disadari pada usia remaja dapat berlanjut hingga usia dewasa dan meningkatkan risiko morbiditas dan mortalitas (Robin, Primayanti and Dinata, 2017). Berdasarkan uraian di atas dapat dilihat bahwa status gizi lebih dan kurangnya aktifitas fisik merupakan aktor risiko tekanan darah tinggi, namun beberapa penelitian belum memfokuskan pada kejadian hipertensi remaja, khususnya remaja akhir berusia 18-19 tahun, maka dari itu peneliti tertarik untuk melakukan penelitian tentang hubungan status gizi dan aktifitas fisik dengan kejadian hipertensi remaja, karena kejadian penyakit pada remaja dapat berlanjut sampai ke dewasa.

\section{METODE PENELITIAN}

Penelitian ini merupakan penelitian kuantitatif dengan menggunakan design cross sectional. Penelitian dilakukan di Universitas Nahdlatul Ulama Sunan Giri pada Oktober-Desember 2019. Populasi pada penelitian ini adalah seluruh mahasiswa S1 Farmasi Universitas 
Nahdlatul Ulama Sunan Giri yang berada rentang usia remaja. Sampel pada penelitian ini sebesar 75 mahasiswa yang diambil dengan metode simple random sampling. Variabel dalam penelitian ini terdiri dari 3 yaitu status gizi, aktifitas fisik dan kejadian hipertensi. Status Gizi dinilai dari Indeks Massa Tubuh (IMT) didasarkan pada hasil pengukuran berat badan (BB) dan tinggi badan (TB) responden. Pengukuran berat badan menggunakan timbangan berat badan, sedangkan pengukuran tinggi badan menggunakan microtoise. Data aktivitas fisik diperoleh dari kuesioner Adolescent Physical Activity and Recall Questionnaire (APARQ). Responden mengisi kuesioner dan menuliskan jenis aktivitas fisik beserta frekuensi dan durasi setiap melakukan aktivitas fisik tersebut kemudian dikalikan dengan skor METs. Aktivitas fisik yang dituliskan antara lain aktivitas olahraga yang dilakukan seperti berjalan, berlari, bersepeda, senam dan lainnya, juga aktivitas fisik domestik seperti menyapu, mengepel, memasak dan lainnya. Aktivitas fisik selanjutnya dikategorikan menjadi Berat, Sedang dan Ringan. Klasifikasi Indeks Massa tubuh (IMT) pada penelitian ini dibagi menjadi 4 kategori yaitu underweight dengan besaran IMT $<18,5$, IMT normal 18,5 - 22,9, kategori overweight 23 - 24,9 dan kategori obesitas > 24,9. Klasifikasi tekanan darah pada penelitian ini diadopsi dari JNC VII 2003 yang dibagi juga menjadi 4 kategori yaitu normal, pre hipertensi, hipertensi tingkat I, dan hipertensi tingkat II. Kategori normal dengan sistolik <120 mmHg dan diastolik $<80 \mathrm{mmHg}$, kategori pre hipertensi dengan sistolik 120-139 mmHg dan diastolik 80$89 \mathrm{mmHg}$, kategori hipertensi tingkat I dengan sistolik 140-159 $\mathrm{mmHg}$ dan diastolik 90-99 mmHg, kategori hipertensi tingkat II dengan sistolik $\geq 160 \mathrm{mmHg}$ dan diastolik $\geq 100 \mathrm{mmHg}$ (Ulumuddin and Yhuwono, 2018). Pengukuran tekanan darah menggunakan tensimeter. Pengukuran tekanan darah dilakukan oleh peneliti dua kali dengan rentang waktu 10 menit antar pengukuran. Metode analisis data menggunakan analisis univariat dan bivariat. Analisis univariat pada penelitian ini dilakukan untuk menggambarkan distribusi Indeks Massa Tubuh (IMT), aktivitas fisik dan tekanan darah. Sedangkan analisis bivariat pada penelitian ini menggunakan uji statistik korelasi spearman pada aplikasi SPSS dengan tingkat kepercayaan $95 \%$ untuk menganalisis hubungan antara status gizi dengan kejadian hipertensi dan hubungan aktifitas fisik dengan kejadian hipertensi.

\section{HASIL PENELITIAN}

\section{Gambaran Umum Responden}

Pada penelitian ini, responden adalah 75 mahasiswa Universitas 
Nahdlatul Ulama Sunan Giri Bojonegoro yang termasuk golongan masa remaja berusia 17-19 tahun dengan distribusi responden menurut jenis kelamin diketahui $81,33 \%$ responden berjenis kelamin perempuan. Distribusi jenis kelamin responden disajikan pada tabel 1 .

Tabel 1. Distribusi Frekuensi Jenis Kelamin Responden

\begin{tabular}{lcc}
\hline $\begin{array}{c}\text { Jenis } \\
\text { Kelamin }\end{array}$ & Jumlah & $\begin{array}{c}\text { Persentase } \\
(\boldsymbol{\%})\end{array}$ \\
\hline Laki-laki & 14 & 18,57 \\
Perempuan & 61 & 81,33 \\
Jumlah & 75 & 100 \\
\hline
\end{tabular}

\section{Gambaran Status Gizi}

Pada penelitian ini dilakukan pengukuran berat badan, tinggi badan dan tekanan darah secara langsung. Penentuan status gizi berdasarkan Indeks Massa Tubuh (IMT) yang dihitung dari berat badan dalam kilogram dibagi dengan kuadrat tinggi badan dalam meter. Hasil intreprestasi IMT selanjutnya digolongkan menjadi underweight, normal, overweight dan obesitas. Status gizi berlebih atau overweight dan obesitas sama proporsinya yakni $20 \%$ Gambaran status gizi responden dapat dilihat pada tabel 2 .

Tabel 2. Distribusi Status Gizi Responden

\begin{tabular}{llrr}
\hline Status Gizi & Jumlah & \multicolumn{2}{l}{ Persentase } \\
& & & 10,67 \\
\hline Underweight & 8 & & 49,33 \\
Normal & 37 & 20 \\
Overweight & 15 & & 20 \\
Obesitas & 15 & & 100 \\
Jumlah & 75 & & \\
\hline
\end{tabular}

\section{Gambaran Aktifitas Fisik Responden}

Aktivitas fisik diukur menggunakan kuesioner meliputi kegiatan atau aktivitas yang biasa dilakukan dari bangun tidur hingga kembali tidur dalam kurun waktu seminggu terakhir. Aktivitas fisik dinyatakan dalam skor yaitu METsmin sebagai jumlah kegiatan setiap menitnya. Distribusi aktivitas fisik responden disajikan pada tabel 3 .

Tabel 3. Distribusi Aktivitas Fisik Responden

\begin{tabular}{lrr}
\hline Aktivitas Fisik & Jumlah & Persentase (\%) \\
\hline Ringan & 44 & 58,67 \\
Sedang & 19 & 25,33 \\
Berat & 12 & 16,00 \\
Jumlah & 75 & 100 \\
\hline
\end{tabular}

\section{Gambaran Tekanan Darah Responden}

Tekanan darah diukur oleh peneliti menggunakan tensimeter $2 \mathrm{x}$ dengan rentang waktu 10 menit tiap pengukuran. Kategori kejadian hipertensi berdasarkan tenakan darah sistolik dan tekanan darah diastolik yang kemudian dibagi menjadi 4 kategori, yaitu normal, pre hipertensi, hipertensi tingkat I, dan hipertensi tingkat II. kejadian pre hipertensi sebesar $16 \%$ dan hipertensi I sebesar 14,67. Sedangkan kejadian hipertensi II hanya sekitar 2,67\%. Kejadian hipertensi responden disajikan pada tabel 4 . 
Tabel 4. Kejadian Hipertensi Responden

\begin{tabular}{lrr}
\hline $\begin{array}{l}\text { Kejadian } \\
\text { Hipertensi }\end{array}$ & Jumlah & $\begin{array}{c}\text { Persentase } \\
(\%)\end{array}$ \\
\hline Normal & 50 & 66,67 \\
Pre & 12 & 16 \\
Hipertensi & & \\
Hipertensi I & 11 & 14,67 \\
Hipertensi II & 2 & 2,67 \\
Jumlah & 75 & 100 \\
\hline
\end{tabular}

\section{Hubungan Status Gizi dengan Kejadian}

\section{Hipertensi}

Hubungan status gizi dengan kejadian hipertensi dilihat berdasarkan analisis korelasi spearman yang dilakukan menggunakan SPSS. Hasil perhitungan analisis bivariat dengan uji Spearman dapat dilihat pada tabel 5. Berdasarkan tabel 5, diperoleh nilai $\mathrm{r}$ sebesar 0.507 dan nilai $\mathrm{p}$ sebesar 0.000 yang menunjukkan bahwa terdapat hubungan korelasi yang kuat antara status gizi dengan kejadian hipertensi remaja.

Tabel 5. Hubungan Status Gizi dengan Kejadian Hipertensi

\begin{tabular}{lcc}
\hline Variabel & $\mathbf{r}$ & $\mathbf{p}$ \\
\hline $\begin{array}{l}\text { Status Gizi } \\
\text { dengan }\end{array}$ & 0.507 & 0.000 \\
Hipertensi & & \\
\hline
\end{tabular}

\section{Hubungan Aktivitas Fisik dengan Kejadian Hipertensi}

Hubungan aktivitas fisik dengan kejadian hipertensi dilihat berdasarkan analisis korelasi spearman yang dilakukan menggunakan SPSS yang disajikan pada tabel 6. Berdasarkan tabel 6, diperoleh nilai $\mathrm{r}$ sebesar 0.408 dan nilai $\mathrm{p}$ sebesar
0.000 yang menunjukkan bahwa terdapat hubungan korelasi yang sedang antara aktivitas fisik dengan kejadian hipertensi remaja.

Tabel 6. Hubungan Aktivitas Fisik dengan Kejadian Hipertensi

\begin{tabular}{lcc}
\hline Variabel & r & p \\
\hline $\begin{array}{l}\text { Aktivitas } \\
\text { dengan }\end{array}$ & 0.408 & 0.000 \\
Hipertensi & & \\
\hline
\end{tabular}

\section{PEMBAHASAN}

Status gizi adalah ukuran kondisi fisiologis seseorang akibat dari konsumsi makanan, penyerapan (absorbsi), dan penggunaan (utilization) zat-zat gizi. Status gizi dapat dinilai dari Indeks Massa Tubuh (IMT). Indeks Massa Tubuh (IMT) yang tinggi disebabkan bertambahnya jaringan adiposit atau peningkatan komposisi tubuh lain (Yunitasari, Sinaga and Nurdiani, 2019). Pada penelitian ini, status gizi lebih, baik overweight atau obesitas memiliki proporsi yang sama, yaitu masing-masing 20\% dan lebih sedikit dibandingkan status gizi normal sebanyak 49,33\%. Hal ini sejalan dengan penelitian yang dilakukan pada mahasiswa tingkat akhir dimana 43,5\% mahasiswa memiliki status gizi normal (Wijayanti, Margawati and Wijayanti, 2019). Hasil penelitian menunjukkan status gizi yang baik pada responden, hal ini disebabkan karena responden merupakan mahasiswa di bidang kesehatan dan pernah mendapatkan 
edukasi terkait status gizi, sehingga sebagain besar responden memiliki status gizi normal. Namun angka kejadian overweight dan obesitas juga harus diperhatikan karena overweight dan obesitas pada remaja akan menetap hingga dewasa dan berisiko terhadap penyakit kardiovaskular (Fayasari, Julia and Huriyati, 2018)

Aktivitas fisik yang baik dan rutin, akan melatih otot jantung dan tahanan perifer yang dapat mencegah peningkatan tekanan darah. Aktivitas fisik merupakan salah satu faktor yan mempengaruhi kejadian hipertensi. Pada penelitian ini, sebagianbesar mahasisawa $(58,7 \%)$ melalukan aktivitas fisik dalam kategori ringan. Hal ini sejalan dengan penelitian sejenis sebelumnya yang menunjukkan sebagian besar aktivitas fisik remaja dalam kategori ringan. Aktivitas fisik ringan lebih banyak ditemukan pada remaja obesitas dibandingkan dengan remaja non-obesitas. Remaja dengan aktivitas fisik ringan berpeluang hampir 5 kali lebih besar mengalami obesitas dibanding dengan remaja dengan aktivitas fisik berat (Iridanty,dkk, 2016). Aktivitas fisik dalam kategori ringan pada responden diantaranya disebabkan karena responden hanya melakukan kegiatan selama sekitar 4 hari dalam seminggu di kampus, dengan aktivitas ringan seperti duduk baik saat jam perkuliahan atau saat istirahat. Pada saat di rumah, sebagian besa responden juga hanya menghabiskan waktu dengan aktivitas fisik yang ringan seperti duduk, membaca dan menonton.

Hipertensi atau yang dikenal dengan tekanan darah tinggi merupakan salah satu penyakit tidak menular yang berupa gangguan pada sistem sirkulasi. Peningkatan tekanan darah dapat terjadi melalui beberapa mekanisme. Pertama, jantung memompa darah lebih kuat setiap detiknya sehingga lebih banyak cairan. Kedua, penebalan dan kakunya dinding arteri terjadi karena adanya aterosklerosis yang terjadi pada lanjut usia. Ketiga, terjadi vasokontriksi yang disebabkan oleh rangsangan saraf dan hormon. Keempat, bertambahnya cairan dalam sistem sirkulasi yang menyebabkab kelainan pada fungsi ginjal yang tidak mampu membuang natrium dan air dalam tubuh sehingga volume darah dalam tubuh meningkat (Putriastuti, 2016). Kejadian hipertensi pada penelitian secara keseluruhan adalah $33,3 \%$, yang terdiri dari pre hipertensi sebesar $16 \%$, hipertensi I sebesar $14,67 \%$ dan hipertensi II sebesar 2,67\%. Proporsi hipertensi yang lebih rendah dibandingkan tekanan darah normal sejalan dengan penelitian yang dilakukan oleh Robin, Primayanti and Dinata (2017) yang menunjukkan prevalensi mahasiswa yang mengalami prehipertensi dan hipertensi sebesar 31,6\% dan yang memiliki tekanan 
darah normal sebesar $67,7 \%$. Banyak faktor yang menyebabkan hipertensi pada remaja. Faktor risiko tersebut dibedakan menjadi faktor risiko yang dapat diubah dan yang tidak dapat diubah. Faktor risiko yang tidak dapat diubah meliputi riwayat hipertensi keluarga, berat lahir rendah, dan jenis kelamin. Sedangkan faktor risiko yang dapat diubah meliputi obesitas, asupan natrium berlebih, kebiasaan merokok, aktivitas fisik, dan kualitas tidur (Shaumi and Achmad, 2019). Angka hipertensi tinggi pada penelitian ini mungkin dipengaruhi oleh beberapa faktor antara lain riwayat hipertensi keluarga, kebiasaan merokok, asupan natrium berlebih dan obesitas.

Hasil penelitian ini menunjukkan adanya hubungan yang kuat antara status gizi dengan hipertensi. Hasil penelitian ini sesuai dengan penelitian tentang hubungan antara status gizi dengan kejadian hipertensi pada dewasa awal yang menunjukkan bahwa terdapat hubungan yang bermakna antara status gizi dengan kejadian hipertensi (Cahyaning, 2017) dan juga penelitian tentang hubungan indeks massa tubuh (IMT) dengan tekanan darah yang menunjukkan terdapat korelasi positif antara IMT/U dengan tekanan darah remaja (Marlina, Huryati and Soenarto, 2016). Status gizi lebih salah satunya disebabkan adanya penambahan berat badan yang berlebih, jika penambahan berat badan disertai peningkatan adipositas viseral, berperan sebagai faktor risiko hipertensi sebesar 65-75\%. Mekanisme terjadinya hipertensi pada obesitas berhubungan dengan resistensi insulin, retensi natrium, peningkatan aktivitas sistem saraf simpatetik, aktivasi sistem renin-angiotensin- aldosteron dan perubahan fungsi vaskular (Mauliza, 2018). Penelitian ini tidak meneliti sampai ke tingkat molekuler, sehingga tidak diketahui secara pasti mekanisme yang menyebabkan adanya hubungan antara status gizi dengan kejadian hipertensi remaja. Dari beberapa mekanisme yang ada, hubungan status gizi dengan kejadian hipertensi dikarenakan adanya peningkatan jaringan adiposa dan perubahan endotel. Hal ini dapat menyebabkan peningkatan tekanan darah melalui reseptor adrenergik. Selain itu, jaringan adiposa juga menyintesis angiotensinogen yang berperan pada aktivasi sistem RAA (Renin-Angiotensin-Aldosteron) dan memengaruhi kadar aldosteron. Aldosteron akan menyebabkan terjadinya peningkatan retensi natrium, sehingga menyebabkan peningkatan tekanan darah.

Hasil penelitian ini menunjukkan adanya hubungan yang sedang antara aktivitas fisik dengan hipertensi. Hal ini terjadi karena responden masih melakukan aktivitas fisik yang rutin setiap minggu sehingga otot jantung tidak harus bekerja 
lebih keras pada setiap kontraksi sehingga tidak menyebabkan meningkatnya tekanan darah. Hasil penelitian ini sejalan dengan penelitian Gusnilawati dan Buston (2016) yang menunjukkan adanya hubungan yang kuat antara status gizi dengan hipertensi dan juga penelitian Iswahyuni (2017) yang menunjukkan ada hubungan antara aktifitas fisik dengan Hipertensi (baik systole maupun diastole). Aktivitas fisik dapat menurunkan tekanan darah melalui mekanisme penurunan tahanan perifer karena adanya perubahan pada aktivitas sistem saraf simpatis dan respon vaskular setelah beraktivitas fisik. Aktivitas fisik juga dapat mensimulasi penurunan aktivitas saraf simpatis dan meningkatkan aktivitas saraf parasimpatis yang menyebabkan vasodilatasi penampang pembuluh darah sehingga terjadi penurunan tekanan darah, baik sistolik maupun diastolik.

\section{KESIMPULAN}

Berdasarkan hasil penelitian, terdapat hubungan yang antara status gizi dan aktivitas fisik dengan kejadian hipertensi remaja.

\section{DAFTAR PUSTAKA}

Abaa, Y. P., Polii, H. and Wowor, P. M. 2017. Gambaran Tekanan Darah, Indeks Massa Tubuh, dan Aktivitas Fisik pada Mahasiswa Kedokteran
Umum Angkatan Tahun 2014. Jurnal e-Biomedik. 5(2):1-5.

Cahyaning, D. 2017. Hubungan Antara Status Gizi Dengan Kejadian Hipertensi Pada Dewasa Awal Di Dusun Bendo Wilayah Kerja Puskesmas Srandakan Bantul Yogyakarta.(Skripsi). Yogyakarta. Universitas Alma Ata

Fayasari, A., Julia, M. and Huriyati, E. 2018. Pola Makan Dan Indikator Lemak Tubuh Pada Remaja. Jurnal Gizi Indonesia (The Indonesian Journal of Nutrition). 7(1): 15-21.

Gusnilawati dan Buston, E. 2016. Hubungan Aktifitas Fisik dan Kuantitas Tidur dengan Kejadian Hipertensi. Jurnal Media Kesehatan. 9 (2) : 114-203

Hardati, AT., dan Ahmad RA.2017. Aktivitas Fisik dan Kejadian Hipertensi pada Pekerja: Analisis Data RISKESDAS 2013. Berita Kedokteran Masyarakat. 33 (10) : 1-9.

Irdiana, W., dan Nindya, T. S. 2017. Hubungan Kebiasaan Sarapan dan Asupan Zat Gizi dengan Status Gizi Siswi SMAN 3 Surabaya. Amerta Nutrition. 1(3): 227-232.

Irdianty, MS., Sudargo, T., Hakimi, M. 2016. Aktivitas Fisik Dan Konsumsi Camilan Pada Remaja Obesitas Di Pedesaan Dan Perkotaan Kabupaten Bantul. BKM Journal of Community Medicine and Public Health. 32 (7) : 217-222.

Iswahyuni, S. 2017. Hubungan Antara Aktifitas Fisik dan Hipertensi pada Lansia. Profesi. 14 (2) : 1-4.

Karim, NA., Onibala, F., dan Kaloo V. 2018. Hubungan Aktivitas Fisik dengan Derajat Hipertensi pada Pasien Rawat Jalan di Wilayah Kerja Puskesmas Tagulandang Kabupaten 
Sitaro. Jurnal Keperawatan. 6 (1) :2836.

Kurnianingtyas, B., Suyatno, S. dan Kartasurya, M. 2017. Faktor Risiko Kejadian Hipertensi Pada Siswa SMA Di Kota Semarang Tahun 2016. Jurnal Kesehatan Masyarakat Universitas Diponegoro. 5(2): 70-77.

Marlina, Y., Huryati, E. dan Soenarto, Y. 2016. Indeks Massa Tubuh Dan Aktivitas Fisik Dengan Tekanan Darah Pada Pelajar SMA. Jurnal Gizi Klinik Indonesia. 12(4): 160-167

Mauliza, M. 2018. Obesitas Dan Pengaruhnya Terhadap Kardiovaskular. AVERROUS: Jurnal Kedokteran dan Kesehatan Malikussaleh. 4(2): 89-96

Praditasari, J.A., dan Sumarmi, S. 2018. Asupan Lemak, Aktivitas Fisik dan Kegemukan pada Remaja Putri di SMP Bina Insani Surabaya. Media Gizi Indonesia 13 (2): 117-122

Putriastuti, L. 2016. Analisis Hubungan Antara Kebiasaan Olahraga Dengan Kejadian Hipertensi Pada Pasien Usia 45 Tahun Keatas. Jurnal Berkala Epidemiologi. 4(2): 225-236

Robin, D.G., Primayanti, I.D., Dinata, IK. 2017. Prevalensi Hipertensi Pada Mahasiswa Semester VI Program Studi Pendidikan Dokter Di Fakultas Kedokteran Universitas Udayana. EJurnal Medika Udayana. 6(2): 1-16.

Setiawati, F. S., Mahmudiono, T., Ramadhani, N., Hidayati, KF. 2019. Intensitas Penggunaan Media Sosial, Kebiasaan Olahraga, dan Obesitas Pada Remaja Di SMA Negeri 6 Surabaya Tahun 2019. Amerta Nutrition. 3 (3): 142-148

Shaumi, N. R. F. dan Achmad, E. K. 2019. Kajian Literatur: Faktor Risiko Hipertensi pada Remaja di Indonesia.
Media Penelitian dan Pengembangan Kesehatan. 29(2): 115-122

Simbolon, D., Tafrieani, W. dan Dahrizal, D. 2018. Edukasi Gizi dan Perubahan Berat Badan Remaja Overweight dan Obesitas. Jurnal Kesehatan. 9(2): 289297

Suryawan, Z.F. 2019. Analisis Faktor Yang Berhubungan Dengan Hipertensi. Skripsi. Surabaya. Universitas Airlangga.

Syahfitri, Y., Ernalia Y., dan Restuasturi, T. 2017. Gambaran Status Gizi Siswasiswi SMP Negeri 13 Pekanbaru Tahun 2016. JOM FK. 4 (2): 1-12

Ulumuddin, I. dan Yhuwono, Y. 2018. Hubungan Indeks Massa Tubuh. 